The Canadian Guide to Britain VOLUME ONE:

ENGLAND 


\title{
The Canadian Guide to Britain VOLUME ONE:
}

\section{ENGLAND}

\section{Jeffrey Simpson Ged Martin}

WITH THE ASSISTANCE OF

Victoria Stewart

\author{
and
}

The Lake St. Louis Historical Society

Macmillan Education 
ISBN 978-1-349-81145-8

ISBN 978-1-349-81143-4 (eBook)

DOI 10.1007/978-1-349-81143-4

Copyright (C) 1985 Jeffrey Simpson and Ged Martin

All rights reserved. The use of any part of this publication reproduced, transmitted in any form or by any means, electronic, mechanical, photocopying, recording, or otherwise, or stored in a retrieval system, without the prior consent of the publisher is an infringement of the copyright law.

\section{Canadian Cataloguing in Publication Data}

Simpson, Jeffrey, 1949-

The Canadian guide to Britain

Includes index.

Contents: v. 1. England

ISBN 978-0-7715-9838-8 (v. 1, bound).

ISBN 978-0-7715-9839-5 (v. 1, pbk.).

1. England-Description and travel-1971-

2. Canadians-England. I. Martin, Ged. II. Title.

DA632-S56 1985 914.1'04858 C84-099744-2

Photo Credits: photos 2, 4, 6, 8, 9, 10, 11, 13, 14, 15, 16, 17 courtesy of British Tourist Authority; photo 7 by Hilda Outridge, supplied courtesy of The Stephen Leacock Memorial Home, Orillia, Ontario; photos 1, 3, 5, 12, by Jeffrey Simpson

Design by Don Fernley

Macmillan of Canada A Division of Canada Publishing Corporation Toronto, Ontario, Canada 
To Wendy, Tait, and Danielle who shared it all 


\section{CONTENTS}

Introduction $\quad x i i i$

\section{London and Area}

Alberta House 2

All Hallows-by-the-Tower 3

Bank of England 3

Beaver House 4

British Columbia House 5

Brown's Hotel 6

Canada Gates, Victoria Memorial 7

Canada House 8

Charles Dickens's House 13

Chislehurst 17

Daily Express Building 18

The Duke of York's Column 22

Greenwich 25

Grey Coat School 27

Houses of Parliament 28

Isleworth 36

Kew Gardens 37

Lincoln's Inn Fields 38

London School of Economics 39

Macdonald House 41

The Maple Leaf Pub 42

The National Portrait Gallery 43

Nelson's Column 46 
viii THE CANADIAN GUIDE TO BRITAIN

Nova Scotia House 47

The Old Vic Theatre 50

Ontario House 51

Orpington 53

Petersham 54

Quebec House 56

Royal Military Academy 57

St. Clement Danes 60

St. Ethelburga-the-Virgin 62

St. Giles Cripplegate 63

St. Katherine Docks 65

St. Margaret's 66

St. Martin-in-the-Fields 74

St. Mary-at-Lambeth 75

St. Mary Woolnoth 77

St. Paul's Cathedral 78

Saskatchewan House 80

12 Upper Brook Street 81

23 Suffolk Street 82

Westminster Abbey 85

\section{The South-east}

Bagshot Park, Surrey 91

Beauport, East Sussex 92

Brookwood Military Cemetery, Surrey 95

Burwash, East Sussex 96

Canterbury Cathedral, Kent 97

Chichester, West Sussex 98

Cranbrook, Kent 99

Eastbourne, East Sussex 103

Farnham, Surrey 104

Firle Place, East Sussex 107

Frant, East Sussex 108

Goodwood House, West Sussex 111

Guildford, Surrey 114

Mickleham, Surrey 116

Newhaven, East Sussex 118

Ripe, East Sussex 121 
Riverhead, Kent 123

Rochester Cathedral, Kent 124

Sissinghurst, Kent 127

36 St. Mary's Terrace, Hastings, East Sussex 128

Throwley, Kent 130

Wakehurst Place, Ardingly, West Sussex 132

Waverley, Surrey 133

West Dean, East Sussex 134

Westerham, Kent 135

Winchelsea, East Sussex 142

\section{South Central}

Aldershot, Hampshire 145

Beaminster, Dorset 146

Bradford on Avon, Wiltshire 147

Canadian Memorial, New Forest, Hampshire 148

Chettle, Dorset 149

Elvetham, Hampshire 150

Nately Scures, Hampshire 151

Old Alresford, Hampshire 153

Poole, Dorset 154

Portsmouth, Hampshire 157

Rowland's Castle, Hampshire 160

St. Andrew's Memorial Church, Isle of Portland,

Dorset 161

Salisbury, Wiltshire 164

Salisbury Plain, Wiltshire 164

Sherborne Castle, Sherborne, Dorset 169

Southampton, Hampshire 170

Stratfield Saye, Hampshire 171

Swanmore, Hampshire 172

Tolpuddle, Dorset 174

Winchester, Hampshire 176

\section{The South-west}

Bath, Avon 181

Bristol, Avon 183

Cannington, Somerset 186 
X THE CANADIAN GUIDE TO BRITAIN

Compton Castle, Devon 188

Dartmouth, Devon 189

Dunkeswell Abbey, Devon 192

Dunsford, Devon 194

Exeter, Devon 195

Falmouth, Cornwall 196

Hatch Court, Hatch Beauchamp, Somerset 198

Newton Abbot, Devon 199

Newton Ferrers, Devon 201

Noss Mayo, Devon 203

Plymouth, Devon 204

Portquin, Cornwall 205

St. Michael Penkevil, Cornwall 206

Wolford, Devon 209

\section{West Central and Wales}

Aston Somerville, Evesham, Worcestershire 212

Blithfield Hall, Rugeley, Staffordshire 214

Caerhun, Wales 216

Cardiff, Wales 218

Clydach, Wales 218

Cotterstock, Northamptonshire 220

Coventry Cathedral, Coventry, Warwickshire 222

Leamington Spa, Warwickshire 222

St. Nicholas, Wales 224

Uppingham, Leicestershire 225

\section{Home Counties}

Aston Abbots, Buckinghamshire 228

Blenheim Palace, Oxfordshire 229

Claydon House, Middle Claydon, Buckinghamshire 230

Cliveden and the Canadian Red Cross Memorial Hospital, Buckinghamshire 233

Ewelme, Oxfordshire 235

Hatfield House, Hertfordshire 236

Hitchin, Hertfordshire 237 
Oxford and Rhodes House, Oxfordshire 240

Reading, Berkshire 247

Ridge, Hertfordshire 249

Runnymede Memorial, Runnymede, Surrey 250

Southill, Bedfordshire 250

Virginia Water, Berkshire 254

Windsor Castle, Berkshire 255

\section{The East}

Cambridge, Cambridgeshire 267

Claypole, Lincolnshire 274

Cottingham, Humberside 275

Hollesley Bay Colony, Suffolk 276

King's Lynn, Norfolk 279

Parish Church, St. Andrew's, Norwich, Norfolk 281

Snake Hall and Moulton, Lincolnshire 283

Snettisham, Norfolk 284

Southwold, Suffolk 285

Spilsby, Lincolnshire 288

Thorpe-le-Soken, Essex 290

\section{North Central}

Bolsover, Derbyshire 295

Chatsworth, Derbyshire 296

Gawthorpe Hall, Lancashire 298

Hartington, Derbyshire 299

Liverpool, Merseyside 300

Matlock Bath, Derbyshire 305

9 Christian Road, Preston, Lancashire 305

Parkgate, South Wirral, Cheshire 307

Shibden Hall, Halifax, West Yorkshire 309

\section{The North}

Alnwick, Northumberland 311

Berwick upon Tweed, Northumberland 316

Castle Howard, North Yorkshire 321 
xii THE CANADIAN GUIDE TO BRITAIN

Cleveland County 323

Middlesbrough 324

Great Ayton 325

Staithes 328

Whitby 328

Dalemain, Cumbria 330

Howick Hall, Northumberland 333

Kiplin Hall, North Yorkshire 335

Penshaw Monument, Tyne and Wear 337

Wylam, Northumberland 341

Appendix 343

Index 345 


\section{Introduction}

How often has it been observed that Canadians know too little about their own history? Study after study has documented this regrettable state of affairs, yet who can say with conviction that our history is better understood now than it was twenty, or even ten, years ago? This book offers a modest contribution to bringing Canadians closer to their history, or at least to that part of their history that lies in what used to be known as the Mother Country.

Why yet another book about Britain? Surely no country has been so thoroughly picked over. Bookshelves fairly groan with guides and "how to" books about Britain which offer the traveller, active or armchair, discriminating or otherwise, everything that could possibly be desired about how to get there; where to eat and stay; how to move about; what to treasure or avoid; how much things cost; how to change money; how to secure tickets to the theatre, a royal garden party, Wimbledon or Glyndebourne; how to understand a Cockney or a Yorkshireman; how to find tube stations and walking paths, stately homes and market squares, pubs and inns, dales and moors, streams and lakes. And yet there is nothing in all this vast and variegated literature that informs Canadians that this too is their country, the place where so much of what we know of Canadian history began.

Leave all the "how to" and "where to" questions for others. This book is about Canada in Britain, the intermingling of two histories, a guide and perhaps an inspiration for the thousands of Canadians who visit Britain every year to look about them and discover part of their country's own history.

No book about Canada's links in Britain could possibly be complete. Millions of Canadians trace their ancestry to 
Britain, and the stories of those ancestors, sometimes recorded but often forgotten, are too voluminous for any historian, or group of historians, to chronicle. These stories form the backdrop for those of the celebrated, the notorious and the comic whose lives stand out in the history books. So we have perforce concentrated on characters and events we believe will be known to most of our readers.

We set for ourselves many tasks but only one rule, which like so many rules we occasionally broke. That rule, imposed by the daunting size of our project, required that the links we traced offer something tangible for the traveller to behold in Britain-a museum, stately home, theatre, church, gravestone, memorial, statue, borstal, bridge, pub, ship, cottage, gate, house, library, town hall, hotel; in short, anything that could be observed. We broke our rule, as discerning readers/travellers will no doubt note, in cases in which a person's contribution to Canadian history was so striking that to have excluded him for lack of suitable commemoration in the land of his birth seemed absurd and unfair. But we have tried for the most part to heed our rule-only links that could be seen with the naked eyeappreciating that no book could capture them all. We hope that, if this book finds sufficient favour to warrant a prolonged life, we shall be able to incorporate in future editions new material-and corrections if need be-from stout travellers and informed readers.

Those of Scottish descent and all others who love Scotland should not despair. Our original intent had been to offer a one-volume account of Canadian links in the whole of Britain. But it became apparent as our work progressed that such a volume would be nearly twice the size (and price) of this one, rather too large we thought for pockets or easy digestion on a long winter's night. So we have split our work, and a second volume will subsequently appear tracing Canada's many links with Scotland. This volume, as the title suggests, deals only with England, a mighty task in itself. 
Doug Gibson, the publisher of Macmillan, first suggested this project, never failed in his enthusiasm for it, and offered throughout that support and advice for which we, like so many Canadian authors, are grateful. Maggie MacDonald, our editor, has moulded more names, places, and dates than she may have ever seen in one manuscript into a comprehensible and we hope entertaining whole. She, too, deserves our thanks.

This book represents not only a discovery for us of Canada's history in Britain, but of Britain itself through her people. Lords and ladies, Members of Parliament and diplomats, vicars and vergers, librarians and recordkeepers, publicans and innkeepers - they all responded in every corner of Britain with curiosity, courtesy, and often indispensable help.

We received invaluable assistance from the late David $\mathrm{M}$. Stewart, President of the Lake St. Louis Historical Society in Montreal. The marriage of our project with Miss Victoria Stewart's extensive research into Canada's heritage in Britain has made this book more complete than it would otherwise have been.

If this book brings Canada's history a bit closer to those travelling in Britain, or reminds armchair readers of stories and people long-forgotten, it will have served its purposes. We are, of course, responsible for any of its failings. 


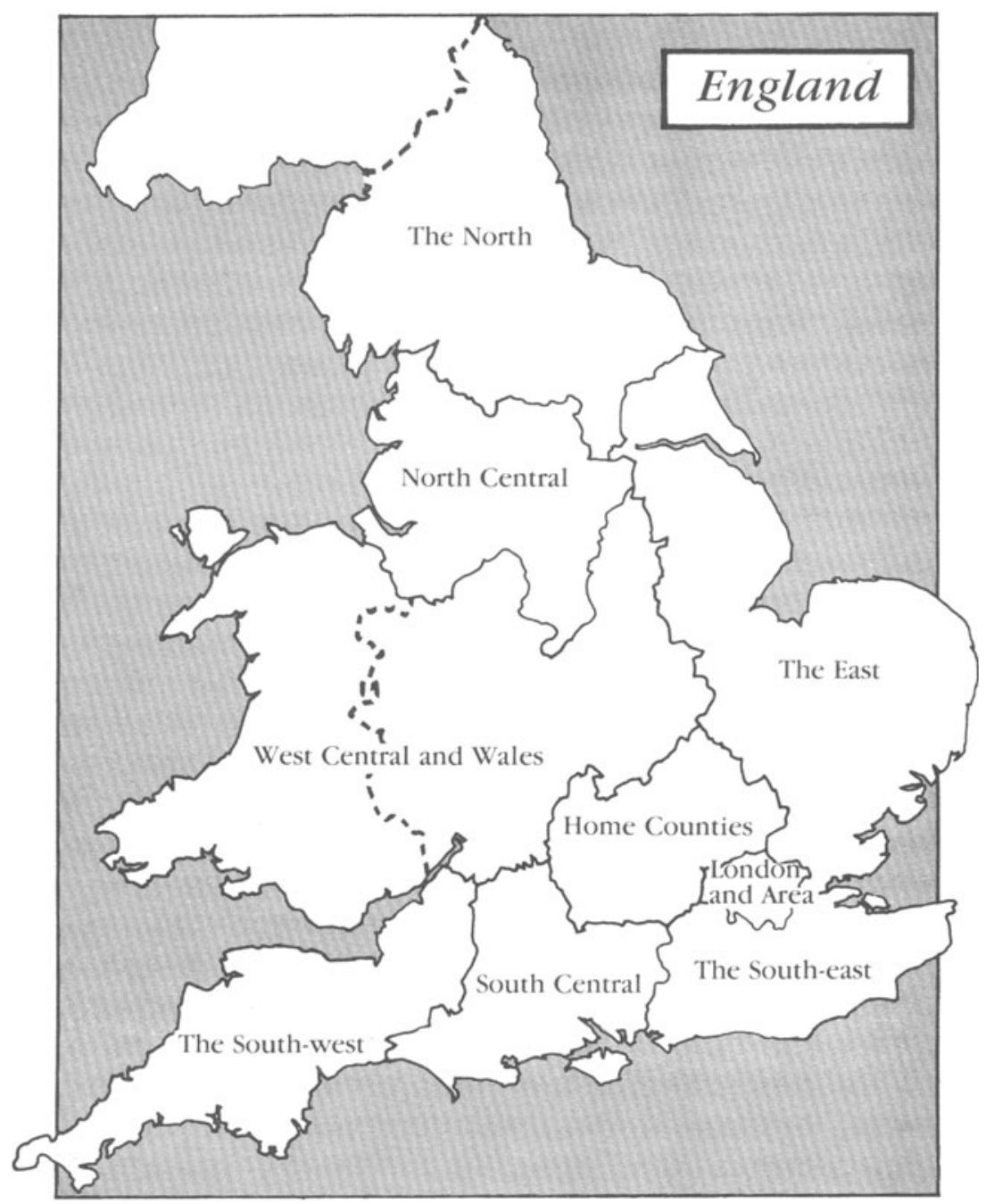




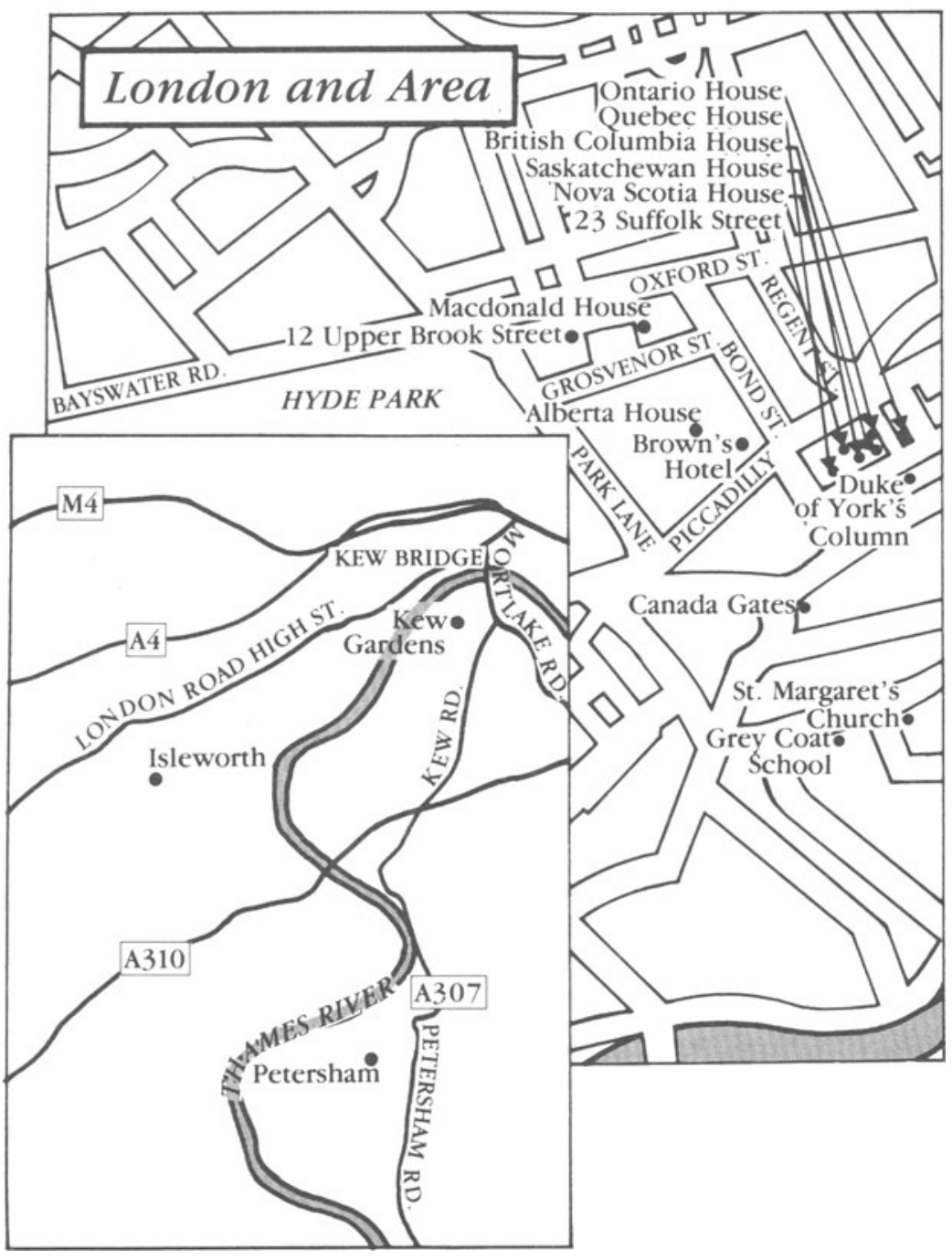

